\title{
Ekstrak Rumput Laut Sargassum sp Mencegah Trombositopenia Gestational pada Tikus Selama Kebuntingan
}

\section{The Extract of Sargassum sp Extract in Preventing Gestational Thrombocytopenia in Rat during Pregnancy}

\author{
Maulida Selma Hanum ${ }^{1}$, Amir Husni ${ }^{2}$, Risa Ummami ${ }^{3)}$, Pudji Astuti ${ }^{4}$, Claude Mona Airin ${ }^{4) *}$ \\ ${ }^{1)}$ Mahasiswa Kedokteran Hewan, Fakultas Kedokteran Hewan Universitas Gadjah Mada, \\ Yogyakarta \\ ${ }^{2)}$ Departemen Perikanan, Fakultas Pertanian Universitas Gadjah Mada, Yogyakarta \\ ${ }^{3)}$ Departeman Tekhnologi Hayati dan Veteriner, Sekolah Vokasi Universitas Gadjah Mada, \\ Yogyakarta \\ ${ }^{4)}$ Departeman Fisiologi, Fakultas Kedokteran Hewan Universitas Gadjah Mada, Yogyakarta
}

Article history

Received: Jan 26, 2020;

Accepted: Mey 25, 2020

* Corresponding author:

E-mail:

monaairin@ugm.ac.id

DOI:

10.46549/jipvet.v11i1.92

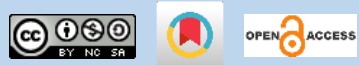

\begin{abstract}
The potential of seaweed as a functional food ingredient has not been explored. Several studies, the compotition of seaweed can prevent stress in animals such as sedative mechanisms. The sedative effect was decreased of blood pressure. Pregnancy can be a stressor in animals and cause anemia physiologically. This study aims to determine the effect of seaweed extract on the profile hemoglobin and erythrocytes of pregnant mice. In this study used 10 pregnant rats divided into 2 groups, group 1 (control) and group II (treatment with $450 \mathrm{mg} / \mathrm{BW}$ extract Sargassum sp). Calculation of erythrocytes, hemoglobin, and thrombocyte measurements were carried out in day 0,7 , and 14 . The results showed that there was an increased thrombocyte count in the treatment group even though in both groups there was a decreased the number of erythrocytes and hemoglobin. The results of statistical analysis showed a significant difference ( $p$ $<0.05$ ) of thrombocyte counts between the control and treatment groups. Based on the results of the study it was found that administration of Sargassum sp. during pregnancy can prevent thrombocytopenia in pregnant rat.
\end{abstract}

Keywords: Sargassum sp; Pregnant rat; Thrombocytopenia; Erythrocytes; Hemoglobin

\section{Abstrak}

Potensi rumput laut sebagai bahan pangan fungsional belum banyak digali. Beberapa penelitian telah menyebutkan kandungan rumput laut dapat mencegah stress pada hewan seperti mekanisme sedativa. Efek sedativa yang sering muncul adalah penurunan tekanan darah. Kebuntingan dapat merupakan stressor pada hewan dan secara fisiologi akan menyebabkan anemia. Penelitian ini bertujuan untuk mengetahui efek pemberian ekstrak rumput laut pada gambaran hematologi tikus bunting. Penelitian ini menggunakan 10 ekor tikus bunting yang dibagi menjadi 2 kelompok yaitu kelompok 1 (kontrol) dan kelompok II (perlakuan ektrak rumput laut Sargassum sp $450 \mathrm{mg} / \mathrm{kg} \mathrm{BB}$ ). Pengambilan sampel dilakukan pada hari ke 0 (sebelum kebuntingan), hari ke 7 dan hari ke 14 (akhir kebuntingan). Pengukuran hematologi sampel meliputi perhitungan eritrosit, pengukuran hemoglobin serta trombosit. Hasil penelitian menunjukkan bahwa terjadi peningkatan jumlah trombosit pada kelompok perlakuan meskipun pada kedua kelompok terjadi penurunan jumlah eritrosit dan hemoglobin. Hasil analisis statistik ada perbedaan yang signifikan $(\mathrm{P}<0,05)$ jumlah trombosit antara kelompok kontrol dengan perlakuan. Berdasarkan hasil penelitian didapatkan 
bahwa pemberian ekstrak Sargassum sp selama kebuntingan dapat mencegah terjadinya trombositopenia pada tikus bunting.

Kata kunci: Sargassum sp; Tikus bunting; Trombositopenia; Eritrosit; Hemoglobin

\section{Pendahuluan}

Sargassum sp merupakan salah satu jenis alga yang termasuk pada kelas Pheophyceae atau ganggang coklat. Polisakarida hasil isolasi rumput laut kelas Pheophyceae ini adalah alginat yang berguna sebagai pembentuk gel dan stabilizer dalam bidang pangan, mempunyai manfaat sebagai antitumor, antimetastasis, antipoliferasi, antivirus, dan antiinflamasi (Muslimin dan Sari, 2017). Rumput laut coklat juga memiliki metabolit sekunder antara lain alkaloid, glikosida, tanin, steroid, yang banyak digunakan dalam dunia farmasi dan pengobatan (Gazali et al., 2018). Nutrisi yang terkandung pada alga laut segar mencapai $94 \%$ dari biomassa alga tersebut (Holdt dan Kraan, 2011). Beberapa manfaat telah ditemukan bahwa kandungan pada alga coklat dapat membantu menurunkan kadar kortisol (Nur'aini et al., 2016); memperbaiki profil biokimia darah tikus stress (Lailatulsifa et al., 2016); sebagai antioksidan, antiviral, antihipertensi dan antidiabetes (Gamal, 2010).

Kebuntingan merupakan stressor fisiologis yang dapat meningkatkan kadar kortisol (Duthie dan Reynolds, 2013). Pada umumnya kebuntingan akan menurunkan jumlah eritrosit, penurunan ini biasanya seiring dengan penuruanan hemoglobin sehingga berdampak pada munculnya anemia. Selain itu pada manusia, selama kebuntingan dapat terjadi trombositopenia gestasional yang dapat membahayakan induk dan anak (Saputra et al., 2018). Menurut Candra et al. (2012), kondisi kebuntingan akan mengubah gambaran hematologi yang bersifat fisiologis. Ekstrak rumput laut dapat meningkatkan aktivitas antioksidan, dan menurunkan peeroksidasi lipid, dimana aktivitas antioksidan mencegah formasi dari oksigen radikal seperti peroksida dan superoksida dismutase yang mana diproduksi selama stress tryptophan (Motarojas et al., 2011). Menurut Tethool dan Purwaningsih (2019) keseimbangan antara radikal bebas dan antioksidan dalam tubuh adalah salah satu yang mempengaruhi kesehatan, asupan antioksidan yang berasal dari pakan tidak dapat mencukupi kebutuhan tubuh. Kandungan Sargassum hystrix yaitu protein, lemak, karbohidrat, vitamin dan mineral. Sargassum sp mempunyai kadar air sebesar $61 \%$ (Murata dan Nakazoe, 2001); abu 14-44\% (Marinho-Soriano et al., 2001); protein 0,5$3,9 \%$, total lemak 9-20\% dan serat pangan 4962\% (Diachanty, 2017). Perlu adanya penelitian mengenai efek ektrak rumput laut Sargassum sp terhadap gambaran hematologi, khususnya pada eritrosit, hemoglobin, dan trombosit sehingga dapat diketahui potensi Sargassum sp. untuk mencegah kejadian anemia dan trombositopenia

\section{Materi dan Metode}

Penelitian ini menggunakan 10 ekor tikus Wistar bunting yang dibagi menjadi dua grup, 5 ekor grup kontrol dan 5 ekor grup perlakuan yang ditempatkan dalam kandang metabolisme. Pakan berupa pellet sebanyak 20 gram/ekor dan minum yakni air RO sebanyak $100 \mathrm{ml} / \mathrm{ekor}$ setiap harinya.

\section{Pembuatan Larutan Ekstrak Sargassum sp.}

Sargassum sp diambil dari Kabupaten Gunung Kidul, Daerah Istimewa Yogyakarta. Pembuatan ekstrak Sargassum sp dilakukan di Fakultas Farmasi Universitas Gadjah Mada. pada dosis tunggal yakni $450 \mathrm{mg} / \mathrm{kg}$ BB yang diencerkan dengan $1 \mathrm{ml}$ larutan NaCMC 0,5\% sebagai suspending agent. Larutan dihomogenisasi dan disimpan dalam lemari oendingin suhu $5-8{ }^{\circ} \mathrm{C}$ sampai digunakan.

\section{Pelaksanaan penelitian}

Tikus bunting ditempatkan secara individu dalam kandang metabolisme pada suhu ruangan rata-rata $25^{\circ}$ dan kelembaban udara $75 \%$. Perlakuan peroral menggunakan sonde $1 \mathrm{ml}$ Aquades bagi kelompok kontrol dan $1 \mathrm{ml}$ larutan ekstrak Sargassum sp pada kelompok 
perlakuan. Pengambilan darah dilakukan pada hari ke-0, 7, dan 14. Darah dianalisa menggunakan mesin Sysmex KX-21 hematology analyzer. Seluruh tahap penelitian telah disetujui oleh Komisi Etik Praklinik LPPT dengan No. 000022/04/LPPT/2018.

Analisis Data
Data dianalisis secara statistik dengan software Statistical Product and Service Solutions (SPSS®) versi 16. Pengujian perbedaan profil darah merah antar kelompok dan waktu perlakuan dilakukan dengan uji One Way ANOVA.

Hasil dan Pembahasan

Tabel 1. Data jumlah eritrosit, Hb, PCV dan Trombosit tikus kelompok kontrol dan perlakuan

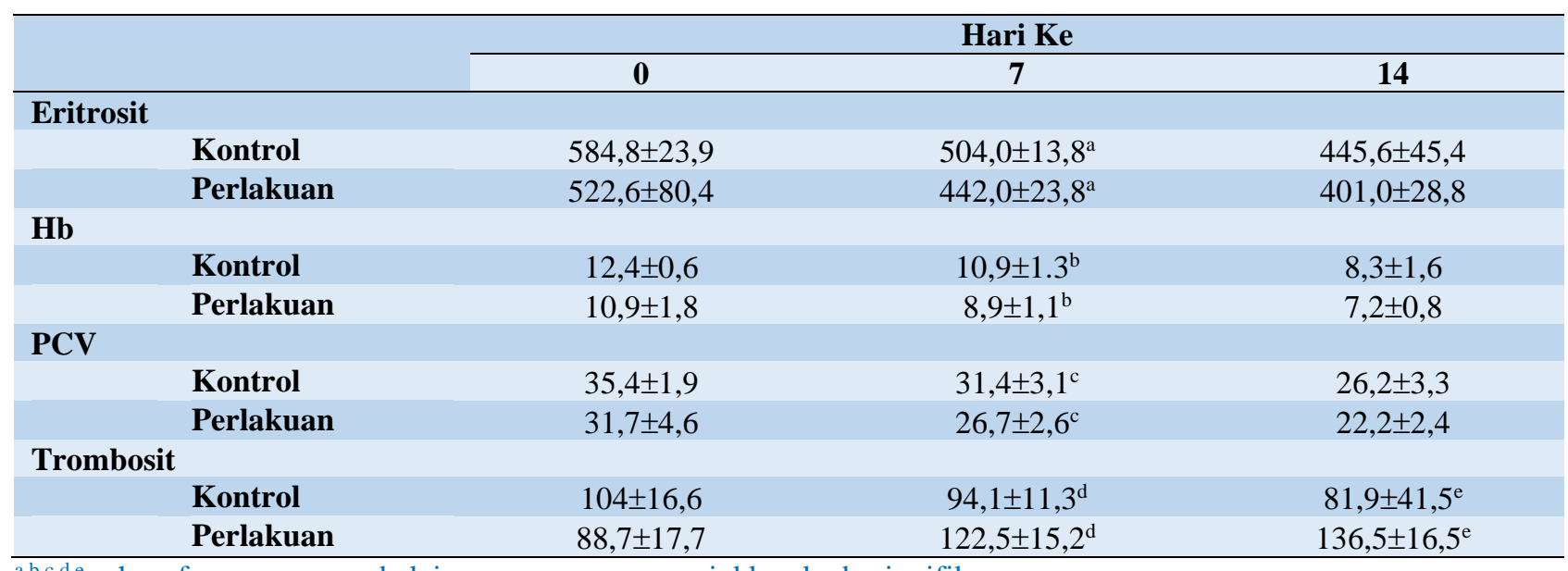

$\overline{\mathrm{a}, \mathrm{b}, \mathrm{c}, \mathrm{d}, \mathrm{e}}=$ huruf yang sama pada lajur yang sama menunjukkan beda signifikan

Pada hari ke-0 sampai hari ke-14, kadar hemoglobin kelompok kontrol mengalami penurunan sebesar $3,6 \mathrm{~g} / \mathrm{dL}$ dan kelompok perlakuan mengalami penurunan sebanyak 3,7 g/dL. Menurut Candra et al. (2012), individu bunting yang mengkonsumsi suplemen zat besi dapat meningkatkan massa sel darah merah, akan tetapi memiliki perubahan yang kurang jelas pada hemoglobin. Menurut Banu dan Mageswari (2015), rumput laut coklat memiliki efek positif terhadap penderita anemia, yakni dapat meningkatkan jumlah eritrosit dan hemoglobin karena memiliki kandungan nutrisi zat besi. Yuniarti et al. (2016) mengatakan bahwa, rumput laut Sargassum sp. dapat meningkatkan kadar hemoglobin pada tikus anemis. Berdasarkan hasil tersebut, dapat dikatakan pemberian ekstrak rumput laut Sargassum sp. tidak mampu mencukupi kebutuhan zat besi dan tidak mampu mengatasi masalah anemia yang dialami hewan coba. Hal ini dapat disebabkan karena kebutuhan zat besi pada saat kebuntingan meningkat dibandingkan dengan kondisi normal. Menurut Yuniarti et al. (2016), pada saat tubuh memerlukan banyak zat besi maka reseptor zat besi akan meningkat, sehingga saat ada asupan zat besi maka tubuh akan langsung menggunakan untuk metabolisme. Selain itu, kemungkinan ekstrak Sargassum sp tidak dapat meningkatkan kadar feritin dalam serum. Feritin merupakan protein yang digunakan untuk penyimpanan zat besi, kadarnya akan menurun saat terjadi pada tahapan awal proses anemia (Mahan et al., 2009). Penelitian yang dilakukan oleh Yuniarti et al. (2016), tikus anemia yang diberi ekstrak Sargasum sp tidak menunjukkan adanya peningkatan feritin. Hasil analisis statistik menunjukkan perbedaan signifikan pada kadar hemoglobin antar kelompok kontrol dan kelompok perlakuan pada hari ke-7 $(\mathrm{P}<0,05)$.

Penurunan kadar PCV kelompok kontrol sebesar $92 \%$ dan kelompok perlakuan $95 \%$. Penurunan kadar PCV dapat disebabkan oleh penurunan produksi eritrosit, kerusakan eritrosit, atau karena pengaruh jumlah dan ukuran eritosit. Kadar PCV yang rendah mengindikasikan adanya kelainan seperti anemia, kerusakan sumsum tulang, hemoragi, kerusakan eritrosit, malnutrisi, myeloma, dan arthritis. Penurunan kadar PCV pada kedua kelompok dapat disimpulkan karena terjadinya anemia saat kebuntingan dan kemungkinan adanya defisiensi zat besi. Menurut Ahmed et 
al. (2018) pada periode kebuntingan akan terjadi peningkatan kebutuhan total volume darah yang diperlukan untuk menjaga homeostasis karena adanya vaskularisasi yang baru dan kemungkinan terjadinya perdarahan. Beberapa yang akan mengalami penurunan adalah jumlah eritrosit dan PCV yang diperlukan untuk hemodilution fisiologis yang terjadi pada kebuntingan (Anberbir et al., 2016 cit in Mubarak et al., 2018). Hasil analisis statistik menunjukkan perbedaan signifikan pada kadar PCV antar kelompok kontrol dan perlakuan pada hari ke-7 $(\mathrm{P}<0,05)$.

Pada kelompok kontrol jumlah trombosit mengalami penurunan pada hari ke -7 dan 14 , sedangkan pada kelompok perlakuan mengalami peningkatan pada hari tersebut. Hasil analisis statistik menunjukkan perbedaan signifikan jumlah trombosit antar kelompok control dan perlakuan pada hari ke-7 dan 14 . Hal ini menunjukan bahwa pemberian ekstrak Sargassum sp dapat meningkatkan jumlah trombosit. Tanin yang terkandung dalam ekstrak Sargassum sp dapat mengendapkan protein dalam albumin, proses tersebut akan merangsang produksi tromboxan (Fauzi et al., 2018). Pada saat kebuntingan, mean trombosit count cenderung menurun dan mengalami trombositopenia gestasi (Reese et al., 2018). Kondisi trombositopenia akan meningkatkan resiko perdarahan pada periode kebuntingan. Pada manusia, angka kejadian trombositopenia gestasional $75 \%$, dimana kasus tersebut lebih banyak menyertai pada pasien dengan riwayat eklamsia dibanding preeklamsia (Saputra et al., 2018). Penurunan trombosit ini merupakan respon fisiologi akibat dari peningkatan agregasi sehingga jika trombositopenia ringan tidak akan mengganggu kesehatan anak dan induk namun pada trombositopenia yang mengikuti kasus medis berat akan berakibat fatal (Ciobanu et al., 2016).

\section{Kesimpulan}

Berdasarkan hasil penelitian, pemberian ekstrak Sargassum sp dosis $450 \mathrm{mg} / \mathrm{kg}$ BB tidak berpengaruh pada jumlah eritrosit, $\mathrm{Hb}$ dan $\mathrm{PCV}$ namun dapat mencegah trombositopenia gestational pada tikus bunting.

\section{Ucapan Terima kasih}

Seluruh tahap penelitian ini didanai oleh Hibah Penelitian Dasar Unggulan Perguruan Tinggi (PDUPT) 2018 dengan nomor kontrak 58/UN1/DITLIT/DIT-LIT/LT/2018.

\section{Daftar Pustaka}

Ahmed WMM, Khalid A and Musa OA. 2018. Effect of Pregnancy on Packed Cell Volume and Total White Blood Cells Count among Sudanese Oregnant Women Attending Anternal Care at Ribat University Hospital (Khartoum State). International Journal of Reproduction, Conception, Obstetrics and Gynecology. 7 (2): 371-374

Banu AT and Mageswari S. 2015. Nutritional Status and Effect of Seaweed Chocolateon Anemic Adolescent Girls. Food Science and Human Wellness 4: 28-34

Candra S, Tripathi AK, Mishra S, Amzarul M, and Vaish AK. 2012. Physiological Changes in Hematological Parameters During Pregnancy. Indian Journal Hematology Blood Transfuion 28(3): 144146

Ciobanu AM, Simona C, Brandusa C, Gheorghe P and Anca MP. 2016. Trombocytopenia in Pregnancy. Maedica (Buchar). 11(1): 56-60

Diachanty S, Nurjanah dan Abdullah A. 2017. Aktivitas Antioksidan Berbagai Jenis Rumput Laut Coklat dari Perairan Kepulauan Seribu. Jurnal Pengolahan Hasil Perikanan Indonesia. 20 (2).

Duthie L and Reynolds RM. 2013. Changes in the Maternal Hypothalamic-Pituitary Adrenal Axis in Pregnancy and Postpartum: Influences on Maternal and Fetal Outcomes. Neuroendocrinology 2013; 98:106-115.

Fauzi A, Lamma S and Ruslin M. 2018. Total Tannin Levels Analysis of Brown Algae (Sargassum sp. and Padina sp.) to Prevent Blood Loss in Surgery. Journal of Dentomaxillofacial Science (J Dentomaxillofac Sci) 3 (1): 37-40.

Gamal. 2010. Biological Importance of Marine Algae. Saudi Pharm. J. 18:1-25

Gazali M, Nururjanah dan Zaanai NP. 2018. Eksplorasi Senyawa Bioaktif Alga Cokelat 
Sargassum sp. Agardh Sebagai Antioksidan dari Pesisir Barat Aceh. Jurnal Pengolahan Hasil Perikanan Indonesia. Volume 21 (1); 167-178

Holdt SL and Kraan S. 2011. Bioactive Compounds in Seaweeds: Functional Food Application and Legislation. Journal of Applied Psychology, 23, 543-597

Lailatulsifa R, Husni A and Nugroho, E. 2016. Anti-stress Activity of Sargassum polysiticum extract Using a Cold Restraint Stress Model. Food Science and Biotechnology

Mahan L, Khathleen and Sylvia. 2009. Krause's Food and Nutritional Therapy. $12^{\text {th }}$ ed. Canada: Saunders

Marinho-Soriano E, Fonseca PC, Carneiro and Moreira WCS. 2001. Seasonal Variation in chemical Composition of Two Tropical Seaweeds. Bio resource Technol. 97:2402 $-2406$

Mota-rojas M, Orozco-Gregorio H, GonzálezLozano M, Roldan-Santiago P, MartínezRodrígue R, Sánchez-Hernández $M$ and Trujillo-Ortega ME. 2011. Therapeutic approaches in animals to reduce the impact of stress during transport to the slaughterhouse: A review. International Journal of Pharmacology 7 (5): 568-578

Murata M. and Nakazoe J. 2001. Production and Use of Marine Algae in Japan. Japan Agr Res Q. 35:281 - 190

Muslimin dan Sari WKP. 2017 Budidaya Rumput Laut Sargassum Sp. Dengan
Metode Kantong Pada Beberapa Tingkat Kedalaman Di Dua Wilayah Perairan Berbeda. Jurnal Riset Akuakultur, 12 (3), 2017: 221-230

Nur'aini LS, Husni A and Airin CM. 2016. Effect of Sargassum Hystrix Extract on Weight and Blood Biochemical Prifile of Wistar Rats Under Condition of Swimming Stress. Proceeding of the 2nd International Conference on Tropical Agriculture. Yogyakarta, 26-27 Oktober 2017.

Pagana KD and Pagana TJ. 2010. Mosby's Manual of Diagnostic and Laboratory Tests, Sixth Edition. Missouri: Elsevier.

Reese JA, Peck, JD, Deschamp DR, Mc Intosh JJ, Knudtson EJ, Terrell DR, Vasely SK and George JN. 2018. Trombosit Count during Pregnancy. New England Journal of Medicine 378:32-43.

Saputra BA dan Puspita RD. 2018. Kehamilan dan Trombositopenia. Medula (8). 1:94 101.

Tethool AN dan Purwaningsih. 2019. Efek Pemberian Ekstrak Kayu (Akway Drymis $S p)$ Terhadap Kualitas Spermatozoa Mencit (Mus Musculus L). Jurnal Ilmu Peternakan dan Veteriner Tropis. 9(1):2431

Yuniarti A, Hadisaputro S dan Nyoman SW. 2016. Pengaruh Pemberian Rumput Laut Sargassum sp. Terhadap Kadar Hemeoglobin dan Feritin Serum. Jurnal Gizi Indonesia Vol. 5 No. 11: 7-13. 